\title{
Cikkismertetés: Hogyan hat az élelmiszerárak változása fogyasztói szokásainkra?
}

\section{Article review: How do food price changes affect our consumer habits?}

\author{
Ismertető: $\quad$ Devosa Iván $\triangle$ \\ Neumann János Egyetem, Pedagógusképző Kar, Egészségtudományi és \\ Egészségfejlesztési Kutatócsoport
}
Ismertetett cikk: Waterlander WE, Jiang Y, Nghiem N, Eyles H, Wilson N, Cleghorn C, Genç M, Swinburn $\mathrm{B}$, Mhurchu CN, Blakely $\mathrm{T}$. The effect of food price changes on consumer purchases: a randomised experiment. Lancet Public Health. 2019 Aug;4(8):e394-e405. doi: 10.1016/S2468-2667(19)30105-7

Beküldve: 2019.01. 18

doi: $\quad$ 10.24365/ef.v61i1.556

Kulcsszavak: élelmiszer; árak; adó; fogyasztás

Keywords: food; prices; tax; consumption

\section{HÁTTÉR}

Az egészségi állapotot befolyásoló élelmiszeradókkal és támogatásokkal kapcsolatos kutatási eredmények többsége egyetlen tápanyag vagy élelmiszer vásárlási adataira és ezek hatásainak megfigyelésére vonatkozik a teljes étrend helyett. Jelen tanulmány célja a véletlenszerüen kiválasztott élelmiszer-árváltozások vásárlásra gyakorolt hatásainak új-zélandi vizsgálata úgy, hogy a szimulált árváltozás a széles körben ismert élelmiszeradó és támogatási politikák (gyümölcs- és zöldségfélék fogyasztási támogatása, cukrosüdítőital-adó, vagy a feldolgozott élelmiszerekre kivetett cukor-, nátrium- és telítettzsírtartalom-adó) intézkedéseit követték. Magyarországon egységesen a chipsadóként is emlegetett népegészségügyi termékadó (neta) vonatkozik ezekre a kategóriákra.

\section{MÓDSZER}

A felnőtt, vagyis legalább 18 éves résztvevők heti öt vásárlást végeztek új-zélandi virtuális szupermarketekben. Minden vásárlási alkalmat véletlenszerűen osztottak el a változatlan árakat alkalmazó kontrollbolt és az egy, illetve több eltérő árképzéssel müködő, támogatásokat és emelt adószintet szimuláló virtuális üzletek között:

1. gyümölcs- és zöldségfogyasztási támogatás (20\%),

2. cukrosüdítő-adó (20\% vagy 40\%),

3. telítettzsírtartalom-adó (2 vagy 4 új-zélandi dollár / 100 g telített zsír),

4. sóadó (0,02 vagy 0,04 új-zélandi dollár / 100 mg nátrium)

5. cukoradó $(0,40$ vagy 0,80 új-zélandi dollár / 100 g cukor)

Fő eredményként a teljes heti bevásárló kosár „egészségességét” értékelték, vagyis az egészséges élelmiszerek mennyiségének a teljes kosártartalomhoz viszonyított százalékát.

\section{EREDMÉNYEK}

2016. február 1. és december 1. között 1132 vásárlót választottak ki véletlenszerűen, akik közül 1038 (91,7\%) legalább egy virtuális üzletben vásárolt, 743 $(71,6 \%)$ pedig mind az ötféle virtuális üzletet meg- 
látogatta. Összességében 4258 vásárlás adatait elemezték a kísérlet során, köztük 645 kontrollvásárlást (változatlan árakon), 2545 vásárlást, ahol egy termék árát változtatták meg, és 1068 olyan vásárlást, ahol két (vagy több) teremék ára módosult. Kontrollkörülmények között a látogatók 67,9\%-a (szórás 13,01) egészséges élelmiszereket vásárolt. Ezt az arányt az ötféle árpolitika közül három növelte szignifikánsan, de kis mértékben (a telítettzsírtartalom-adó abszolút különbséget jelentett 1,77\%-kal, 95\% megbízhatósági tartomány (MT) 1,03-2,52, p<0,0001; a cukrosüdítő-adó 1,09\%-kal, 95\% MT 0,26-1,91, p=0,0099; és a sóadó: 1,31\%kal, 95\% MT 0,50-2,13, p=0,0016). A cukrosüdítőadó, valamint a gyümölcs- és zöldségtámogatás nem szignifikánsan, 0,18\%-kal növelte a gyümölcseladásokat ( $95 \%$ MT $-0,45-0,85, p=0,60$ ) és $0,41 \%$ kal a zöldségek vásárlását (95\% MT -0,26-1,07, $p=0,23$ ). Mind a telítettzsírtartalom-adó, mind a sóadó a következő fontos helyettesítő hatásokat eredményezte: a gyümölcs- és zöldségfélék vásárlásának százalékos növekedése az összes élelmiszervásárlás tömegére vonatkoztatva (telítettzsírtartalom-adó: 4,0\%, 95\% MT 0,9-7,1; sóadó: 4,3\%, 95\% MT 0,9-7,7); emellett ugyancsak megnőtt a cukorfogyasztás a teljes energia százalékában (telítettzsírtartalom-adó 5,0\%, 95\% MT 2,1-7,9; sóadó 3,2\%, 95\% MT 0-6,5).

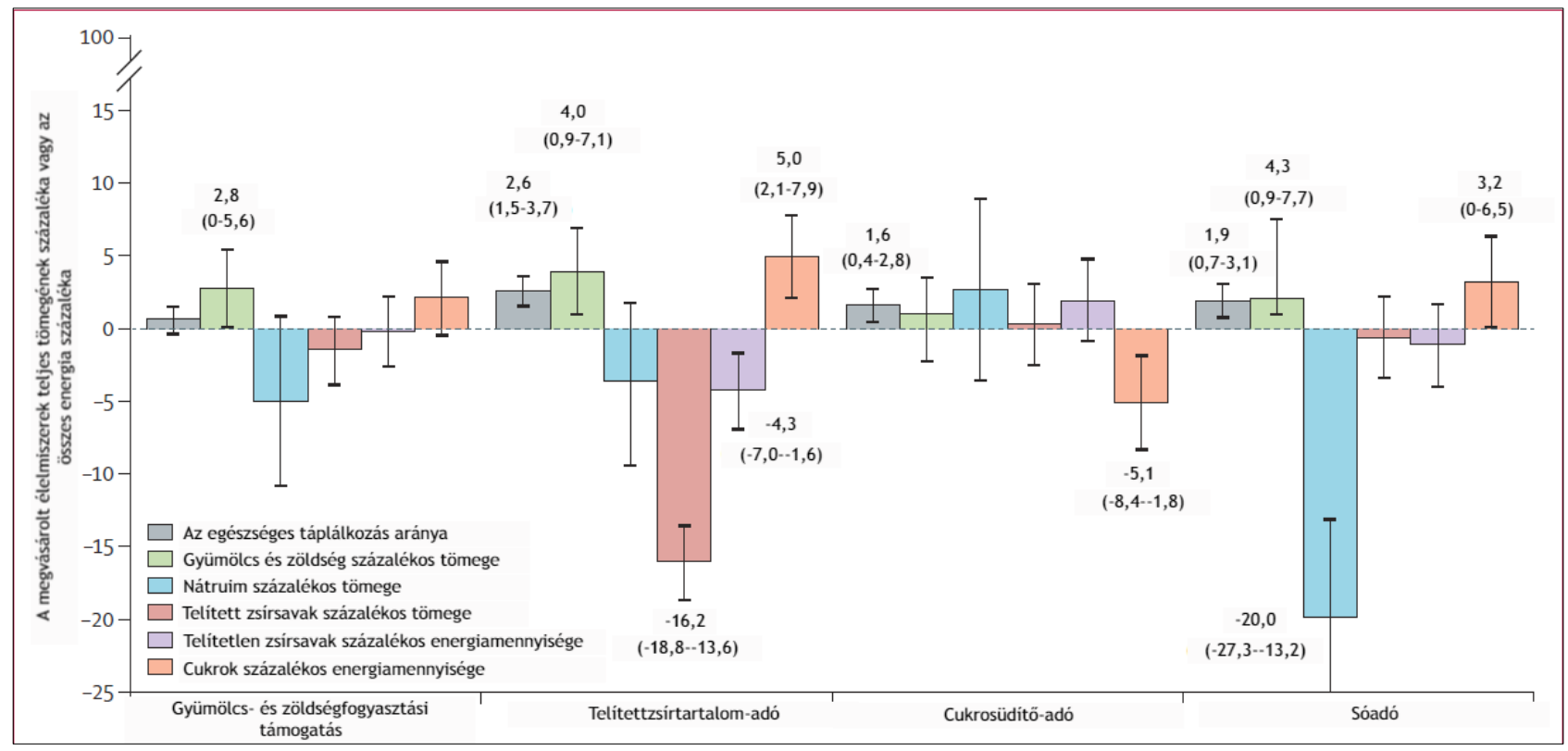

Forrás: Az eredeti ábra magyar változata

\section{KÖVETKEZTETÉSEK}

A telítettzsírtartalom-, cukrosüdítő- és sóadót beépítő árváltozások hatására arányaiban több egészséges ételt vásároltak a kísérlet résztvevői. A tanulmány szerzői fontos helyettesítési hatásokat tártak fel a vásárlások során, így az új-zélandi kísérletben is bebizonyosodott, hogy az adó- és támogatási rendszerek kombinációja lehet a leghatékonyabb módszer az étrend minőségi javítására és az étkezéssel kapcsolatos, gyakran krónikus betegségek számának csökkentésére. 


\section{TANULSÁGOK A HAZAI SZAKEMBEREK SZÁMÁRA}

Magyarországon a már múködő neta tölti be ezt a funkciót, mely 2020. január 1-én további 20 százalékkal emelkedett. Emellett fontos lenne egy olyan rendszer kidolgozása - akár a neta terhére is -, ami az egészséges élelmiszerek fogyasztását támogatja az áfakulcs csökkentésével. Megfelelő tervezés esetén az áfa összegének kiesését közvetlenül ellensúlyozhatná a netából származó bevétel, de az igazi nyereség az egészségben, munkában töltött hosszabb idő, és az abból származó adóbevételek, valamint a csökkentő egészségügyi kiadások lennének.

\section{KÖSZÖNETNYILVÁNÍTÁS}

Köszönettel tartozunk a publikálás támogatásáért, amely az EFOP-3.6.1-16-2016-00006 „A kutatási potenciál fejlesztése és bővítése a Neumann János Egyetemen” pályázat keretében valósult meg. A projekt a Magyar Állam és az Európai Unió támogatásával, az Európai Szociális Alap társfinanszírozásával, a Széchenyi 2020 program keretében valósul meg. 